\title{
Refusal of Youth to Vote in Shah Alam, Selangor, Malaysia
}

\author{
Mohd Ramlan Mohd Arshad *and Norhayati Mohd Salleh \\ Faculty of Administrtaive Science and Policy Studies, Universiti Teknologi MARA Kampus Seremban, Negeri Sembilan, Malaysia \\ *Mohd Ramlan Mohd Arshad, \\ *Corresponding author E-mail: ramlanarshad@gmail.com
}

\begin{abstract}
The involvement of youth in today's politic will influence the future state of Malaysia. The aim of this research is to study on the antecedents that make youth refuse to vote in Shah Alam. The respondents for this research are the youth whom registered as voter for Shah Alam Parliamentary seat. The main objective of this study is to determine the most significance factor that affected their voting behavior. The respondent of this study was 150 youth voters. Purposive sampling technique have been used with questionnaire as the instruments for collecting data. In determining the relationship between the voting refusal behaviors, Correlation Analysis and Regression Analysis were used. Based on the findings, ignorant is the main antecedent of youth refusal to vote in election. Hence, the government, political parties Election Commission of Malaysia and all beneficiaries must work together to ensure our youth ex posed to political system and encourage them to involve in selecting the leaders.
\end{abstract}

Keywords: Youth, Refusal, Vote, Election, Democracy, Parliamentary

\section{Introduction}

Malaysia practices parliamentary democracy where the leader of the country will be selected through the election process which the citizen plays major role in this system. The political parties which received the most votes will be given a mandate by the people to govern the country. The political representative expected to fulfil the needs of the people. Election is imperative elements in democracy system. In Malaysia, an election was held before independence in 1955 and after independent in 1959 and the election was organized in every 5 year 12 . Nowadays, young people have been found to be particularly lack of investment in the political system that has deteriorating effects upon their citizenship. In term of attitudes, some youth are likely to hold a set belief that is specific to their life experiences and pre-adult socialization15. Youth are the next generation who will be the leader of the Nation21. Besides that, youths are the anchor of sustainable development of a country. Everyone has a philosophical, cultural autonomy, particularly in determining the direction of each14. Trusts, supports and commitments from the youth are the core elements for a success of a country. As once quoted by President of Indonesia, Soekarno, "Beri aku 1,000 orang tua, niscaya akan kucabut semeru dari akarnya, beri aku 10 pemuda niscaya akan kuguncangkan dunia"9.

The involvement of youth in today's politic will influence the future state of Malaysia. Every individual has the right to choose whether to be involved in the politic or not. Nevertheless, every individual need to have the responsibility to decide on the most reliable administer to manage our country15. According to Suffian (2013), youths are regarded as the future leaders and they will replace the current leaders in Malaysia and they will soon inherit the nation's pride12

Youth participation in politic is decreasing throughout the whole world. Research done by United Nation Youth Assembly (2016) found that "Participation of young people in formal, institutional political processes is relatively low when compared to older citizens across the globe"

\section{Voting Behavior}

The Psychological Model of Voting Behaviour is a study conducted by the Survey Research Centre at the University of Michigan during 1948 in U.S. This model has always been used to determine the antecedents for each voting behaviour resulted for each election process. Psychological Model of Voting Behaviour is the strongest model that could be used to describe the voting behaviour among youth in Malaysia

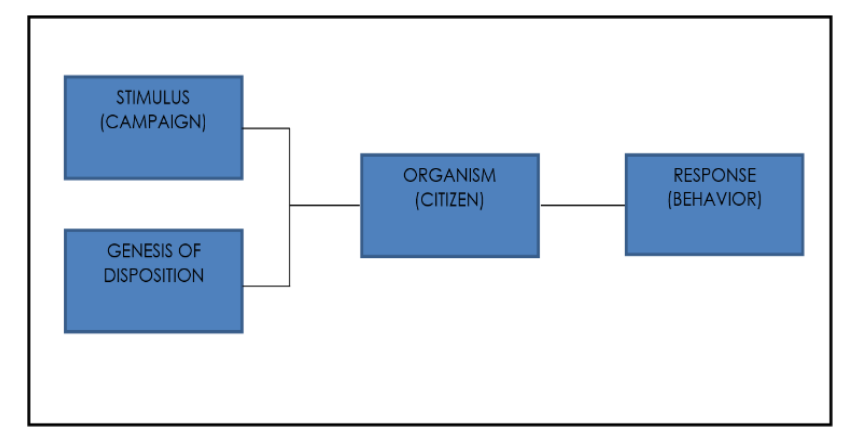

Figure 1: Psychological Model of Voting Behavior. Source: Berelson et al., 1954, p. 278

This psychological model is the study of major factors as relevant to an individual's decision to vote and his choice of candidates to rule a country. The identified factors can be divided into six, which are (1) party identification; (2) sensitivity towards issues; (3) degree of attachment to candidates; (4) conformity to the group standards; (5) sense of efficacy; (6) degree of civic obligation and responsibility to vote. The attitudinal factors 
constitute the motivational patterns of voting behavior. The more the supporting direction of the above three antecedents is invariable, the more the voting consistency can be maintained In this research, this model was tested in determining the youth voting behaviour in Shah Alam Parliamentary Constituency. Malaysian Election Commission (EC) has reported that up to December 2006, 70 percent of the 4.9 million people Malaysia do not register as voters, and they consist of a group of young, aged between the ages of 21 to 35 years22. In addition, "On the 2007, the Election Commission (EC) was announced that there was a total of 4.9 million people eligible to vote have not been register as voters 23 . Of this amount, 80 per cent consisted of those aged 21 to 30 years" 23 . As we can see, the youth contribution towards politic is lower because there is a lack of awareness about the important of vote and their attitudes towards political system in this country. The percentage of citizen casted their ballot in Malaysia General Election 12 is at 76 percent which is equal to 8 million voters5. This number inclined in General Election 13 to 10.4 million voter whom turned out which is equal to $80 \%$, thus Election Commission declared this as the highest percentage of voter turned out in Malaysia's election history5. Figure 2 provide clear picture on the performance of the ruling party-Barisan Nasional as compared to the opposition pact-Pakatan Rakyat, however the opposition pact called as Pakatan Rakyat dissolved officially on 16 of June 20161.

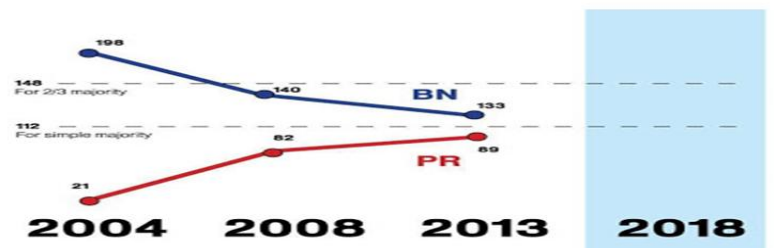

Figure 2: The performance of Barisan Nasional and Pakatan Rakyat. Sources: Election Commission of Malaysia

Even though the total voter turnout in the last election is 80 percent, however the percentage of youth whom casted their ballot is slightly low which is only 60 percent youth turned out. Figure 3 provide explanation on the voting behaviour among youth during the General Election for Selangor and Perak.

\begin{tabular}{|l|l|l|l|}
\hline & Age 21-29 & Age 30-79 & Age 21 - 79 \\
\hline Selangor and Perak & $62.4 \%$ & $62.1 \%$ & $62.1 \%$ \\
\hline
\end{tabular}

Figure 3: Youth turned out in General Election 13. Source: Election Commission of Malaysia

Another issue that raised among this generation is they are more likely to focus on education and employment to build a better life ${ }^{3}$. However, there are still many people in this country who are still ignoring the responsibilities as voter. In other words, they do not vote during election process even they are eligible to vote. So, democracy will not be fully achieved in a country if the citizens do not take it seriously. In addition, the factor that contributes to the refusal of youth to vote in election is because of the decrement of trust towards the government. The excuse given by youth is their votes will not influence the government policies and the future of Malaysia. Votes are supposed to be counted no matter how bad the impact towards a country ${ }^{23}$. The refusal of youth to vote should not be taken lightly by the government especially when the government had lost the trusts from the youth whom in the future will replace the current leaders and will lead the future of our country. Based on finding by Amin (2010) as cited in Mohd Fuad and Junaidi (2012), it was found that the trainee teachers from Maktab Perguruan Perempuan Melayu, Melaka (MPPM) think that politic is full of drama and hoaxes ${ }^{9}$. This is because they perceived political system can be manipulated and will be used to serve the personal interests of certain activists. Another issue that rise among Malaysian citizens is regarding the reliability of the
Election Commission of Malaysia (SPRM) staff in handling the election process ${ }^{19}$. Hence, based on the researches done, it had been proven that youth are having difficulties to trust and to rely on the government integrity. So, this study was undertaken to determine the factors contributing to the reluctance of young people to vote.

\section{Methodology}

The main purpose of this research study is to investigate on the determinant factors that may led to the refusal of youth in Shah Alam to vote thus it uses quantitative research design with cross sectional methodology which is defined as an effort undertaken in which data are gathered once, or over period of days, weeks, or months to satisfy the research question (Sekaran and Bougie, 2013). 150 youth in Shah Alam representing the unit of analysis for this specific survey due to several factors that contributed to the eligibility of the scope of area, which are; it consists of three main races in Malaysia, Malay, Chinese and Indian. This sample is adequate to fulfil the statistic requirement for the study however the number is too small to represent total youth in Shah Alam. Thus, generalization cannot be made through the finding of the study. Researchers decide to use purposive sampling technique to select the samples size. This technique of sampling is a type of non-probability sampling method that depends on data collection from the targeted population members who are conveniently able to be engaged in the study and based on the objective of this study, researchers choose Shah Alam as the scope since the composition of the voters are $44 \%$ Malays, 35\% Chinese and 18\% Indians which satisfied the research requirements. Other than that, researchers have set the criteria in choosing the sample which is must be voter that register under Shah Alam parliamentary seat and age from 21 years old to 40 years old only. In this study, researchers used interval scale and a set of statement provided which required the respondents to rate using Likert Scale, the language used in the questionnaire are English and Malay. This is to ensure that the respondents shall respond to each question without any hesitation.

\section{Results}

\subsection{Test of Normality}

In this study, the researchers use statistical methods and for this specific method, it includes diagnostic hypothesis test for normality. The rule of thumb mentions the value for skewness and kurtosis is between -2 and +2 which can be considered as normal distribution. Table 1 below shows the results for the normality test.

Table 1: . Normality Test (n:150)

\begin{tabular}{|c|c|c|}
\hline Variable & Skewness & Kurtosis \\
\hline Voting Behaviour & -0.911 & 0.619 \\
\hline Ignorant & 0.356 & -0.106 \\
\hline Complacent & 0.311 & 0.600 \\
\hline Trust & -0.290 & -0.122 \\
\hline
\end{tabular}

As it has been mentioned above, per the rule of thumb all the results found for this normality test which had been conducted to satisfy this research study fell within the range of -2 and +2 . Hence, the normality test is considered normal.

\subsection{Descriptive Analysis}

Table 2: Profile of Respondents (n:150)

\begin{tabular}{|l|l|l|}
\hline \multicolumn{3}{|c|}{ Table 2: Profile of Respondents (n:150) } \\
\hline Profile & Frequency & Percentage (\%) \\
Gender & & \\
Male & 73 & 48.7 \\
Female & 77 & 51.3 \\
\hline
\end{tabular}




\begin{tabular}{|l|l|l|}
\hline Age & & \\
$21-25$ & 93 & 62 \\
$26-30$ & 28 & 18.7 \\
$31-35$ & 18 & 12 \\
$36-40$ & 11 & 7.3 \\
\hline Race & 109 & \\
Malay & 21 & 72.7 \\
Chinese & 18 & 14 \\
Indian & 2 & 12 \\
Others & & 1.3 \\
\hline Level of Education & 23 & \\
SPM & 9 & 15.3 \\
STPM & 20 & 6 \\
Diploma & 82 & 13.3 \\
Degree & 13 & 54.7 \\
Master & 3 & 8.7 \\
PHD & & 2 \\
\hline Level of Income & 65 & \\
<RM900 & 34 & 43.3 \\
RM900-RM1699 & 22 & 22.7 \\
RM1700-RM2599 & 13 & 14.7 \\
RM2600-RM3499 & 16 & 8.7 \\
>RM3500 & & 10.7 \\
\hline
\end{tabular}

The result shows female contributed 51.3 percent of the total percentage meanwhile male had answered 73 questionnaires which is equivalent to the percentage of 48.7 percent. Next, is for the age category, most of the respondents aged 21-25 years and Malays answered 109 questionnaires which is equivalent to 72.7 percent while remaining ethnics also respond to the study. For the level of education, it ranges from SPM, STPM, Diploma, Degree, Master, and PHD. The highest frequency of respondents who completed the questionnaires is among Degree level with 82 people and this is equivalent to 54.7 percent which contributed more than half of the total respondents followed by SPM, Diploma, Master, STPM and PHD. Meanwhile, the level of income category has been dominated by those who earn less than RM900 monthly with total respondents of 65 (43.3\%) while the range of salary between RM2600 - RM3499 had possessed the lowest percentage in this research study.

\subsection{Correlation Analysis}

Table 3: Pearson Correlation (n:150)

\begin{tabular}{|l|c|c|c|c|c|}
\hline Variable & & 1 & 2 & 3 & 4 \\
\hline 1.Voting Behaviour & & - & & & \\
\hline 2. Ignorant & & $0.400^{\times \times}$ & - & & \\
\hline 3. Complacent & & $0.273^{\times \times}$ & $-0.465^{\times \times}$ & - & \\
\hline 4. Trust & & $0.367^{\times \times}$ & $0.410^{\times \times}$ & $0.585^{\times \times}$ & - \\
\hline
\end{tabular}

$* * \mathrm{p}<.005$

Table 3 shows that there is relationship between ignorant, complacent and trust and voting behaviour among youth. Ignorant have 40 percent relationship on voting behaviour while complacent and trust bring 27.3 percent and 36.7 percent respectively. Ignorant has significant relationship with $\mathrm{r}=.400, \mathrm{p}<$ .005 , Complacent $(\mathrm{r}=.273, \mathrm{p}<.005)$ and while Trust positive significantly correlate with $\mathrm{r}=.367, \mathrm{p}<.005$.

\subsection{Regression Analysis}

Table 4: Regression (n;150)

\begin{tabular}{|c|c|}
\hline Variable & Standardized, $\beta$ \\
\hline $\begin{array}{l}\text { Ignorant } \\
\text { Complacent } \\
\text { Cack of Trust } \\
\text { R2 } \\
\text { Sig } \\
\text { D-WV }\end{array}$ & $\begin{array}{l}\text { 0.305* } \\
0.016 \\
0.2511^{* 4} \\
0.2100 \\
0.09013 \\
1.383\end{array}$ \\
\hline
\end{tabular}

Dependant Variable: Voting Behaviour

$* \mathrm{p}<.005$

Based on table 4, there is significant link between ignorant and lack of trust. However, ignorant coefficient value slightly higher than lack of trust which is $\beta=.305$ as compare to lack of trust $\beta=.251$. Thus, from the regression analysis, ignorant is the main attribute that lead to youth refusal to cast their ballot during the general election.

\section{Discussion}

Davies mentioned youth in Britain in this era had given less supports towards political system compared to the 1990s17. Besides that, he also thinks that today's youth are more cynical towards political party and arising issues. Greenhouse said, from her research made towards youth age 18-29 years old in America, $45 \%$ said they would not call themselves as supporters, $43 \%$ said they were not sure while only $18 \%$ said that to be involved with the political system is the only way to solve significant issues facing the United States7. Based on a research done by Bustein towards election system in United States, most citizens agreed that there are ignorant young voters 14. A study done by Bartels found that political ignorance of the public does gives impacts not only to an individual vote but also to the election results or outcomes6. This is parallel with the statistic that show even though there is increasing in the number of youth enrolled in college, however the voter turnout among the youngster is declining significantly 21 . It is widely agreed that different age groups and generations have different political leanings, as discussed in the Pew Research Centre's report that two-thirds of voters between the ages of 18 and 24 voted for Barack Obama in 2012 and Bernie Sanders has received a clear majority of the youth vote in the primaries and caucuses that have occurred so far $4,5,21$. However, the political leanings of the young tend to not be represented in the demographics of elected officials because young people vote at such a low rate4,5. The same phenomenon also existed in Britain, as ver the past decade, there has been growing anxiety within government circles that people in Britain are becoming increasingly disengaged from the formal political process and from democratic institutions 7 . This concern has come to the fore largely because of the recent decline in voter participation rates 19 . For instance, election turnout has taken a steep turn downwards, most notably at the landmark General Election of 2001 when only $59 \%$ of the eligible electorate voted 18 . Although voter turnout at subsequent general elections has increased marginally to $61 \%$ in 2005 , and then to $65 \%$ in 2010 , these figures should be put into context by comparing them with previous general election outcomes where electoral participation was $75 \%$ in $1987,78 \%$ in 1992 , and $71 \%$ in 19978 .

Ignorant is a controllable factor which had driven youth in Malaysia to avoid voting and increase the refusal rate to vote. This situation occurs when there are individuals who are lack of responsibility towards the future of Malaysia, however, the government should not put the blame on youth entirely whereas, a research study need to be conducted to investigate such assumption. In addition, high number of voters regardless of age are increasingly ignorant of basic facts about their own government and politics2. According to Mohamad Agus, most of youth nowadays have lack of awareness regarding their rights to vote and he added, nearly 4.39 million of eligible voters have not yet registered and $65 \%$ of them are Bumiputera24. Such scenario shall not be presence among youth if their level of ignorance is low and they will eventually take part in each voting as they are aware of their responsibility as a true Malaysian. Based on above facts, it is proved that refusal of youth to vote due to ignorant are global phenomenon. Malaysia is not excluded with such disease as based on research done on 5,200 students from 20 Public Higher Education Institution, youth are prone to vote for a political party which has specific aim, and a clear direction to lead and to administer the country11. Sarjit et al., stated that Malaysian youth do not perceive voting as a priority in their life 18. Hence, voting is no longer considered as a duty for every Malaysian youth who had reached 21 years old to register or to choose the best candidates to manage and to administer the country. 
Not only academician, but majority people do agree that youth are the future leader of the nation. Thus, they need to be exposed to the political system to ensure they are not inherited the weakness from the previous premiership. This is because, the effects of weak leadership will remain for the next decade in the nation Although the result cannot be used to make a general assumption toward youth refusal to vote as there are various limitation for this study, it can give basic ideas especially for the ruling party to win the heart of the youth to vote for them in the next election. Youth today are more educated, and they have their own ideology and understanding about politics. Thus, they need to be channel to the right way to ensure they are not becoming the victim of politics especially by the foreign entities. This is very important as the revolution that occurred outside Malaysia have proved that the youth are the anchor in changing the political system. As mentioned before, youth are the future leaders and today's leaders must always keep the youth closer to them to enhance their leadership skill and to become good leaders in the future. The political representatives must always involve and participate in each program which involved the youth to encourage a good relationship between the leaders and the youth. Most of the political representatives will only move closer to the public during the election time and this will not enhance the level of trust of the youth towards the candidates. The candidates too must always be reminded that transparency and integrity of an individual will always be the important factors to encourage the youth to vote as they value such qualities. Hence, a one-day program with youth will not going to change the perception of youth towards the political parties. It is important for political representatives to study the behaviour of the youth to attract them to vote, and to understand their way of thinking as today's youth are far too different from the 60 s and 70 s youth.

\section{Conclusion}

This study was conducted to investigate the factors that contribute to the refusal of Malaysian youth to vote in Shah Alam. As for this research study, there were three main objectives that need to be fulfilled by the researchers to complete this study. The first objective was to analyze the antecedents for youth in Shah Alam to become ignorant towards the obligation of voting. The second objective was to examine the level of trust towards candidates and the election system among youth in Shah Alam. The third objective was to investigate whether complacent of life is one of the factors that may affect the voting behavior of youth in Shah Alam. In wrapping this issue, the government and other political parties must always use new approaches to attract the interest of the Malaysian youth to vote. The Malaysian youth must be reminded on their responsibility to vote as a Malaysian. Based on the findings, ignorant and lack of trust towards the candidates and the election system must be given an intensive attention by the political parties to gain the interest of the youth and to increase the level of trust of youth. The future of Malaysia is in the hand of today's youth as they will become our future leaders thus, their participation is highly needed.

\section{Acknowledgement}

The authors gratefully acknowledge the help of the Dean and staffs of Faculty of Administrative Science and Policy Studies, UiTM Kampus Seremban 3, the Election Commission of Malaysia Shah Alam and to all whom directly and indirectly involved in completing this research.

\section{References}

[1] Astro Awani. Pakatan rakyat kini tinggal sejarah. Retrived http://www.astroawani.com/berita-malaysia/pakatan-rakyat-kinitinggal-sejarah-netizen-62675 (accessed on 1 September 2016).
[2] C. S. Elmendorf and D. Schleicher. Informing Consent: Voter Ignorance, Political Parties, and Election Law. University of Illinois Law Review, 2013(2), No. 2, 363-432. (2013)

[3] D. Meyer. How the German Pirate Party Liquid Democracy Works, Tech Presiden (2012).

[4] Desilver, Drew. "The Politics of American Generations: How Age Affects Attitudes and Voting Behavior." Fact Tank, (2014).

[5] Election Commission. Keputusan pilihanraya umum 12. Available at http://semak.spr. gov.my/spr /laporan $/ 5$ KedudukanAkhir.php (2008).

[6] Election Commission. Keputusan pilihanraya umum 13. Available at http:/ resultpru13. spr.gov.my/ module/ keputusan/paparan/paparan_laporan.php (2013).

[7] H.D Clarke, D. Sanders, M.C Stewart and P. Whiteley. Political Choice in Britain. Oxford: Oxford University Press (2004).

[8] H. Matthews. Citizenship, youth councils, and young people participation. Journal of Youth Studies, 4 (3), 299-318 (2001).

[9] L. Bartels. The Study of Electoral Behavior. Oxford Handbooks Online (2010).

[10] L. Greenhouse. Law and Politics. The New York Times (2014).

[11] M. J. Mohd Fuad and A. B. Junaidi. Opinion and the Needs of Young Generation in Muar Parliamentary constituency, Johor, EBangi, 7(1), 50-63 (2012).

[12] M. J. Mohd Fuad, I. Yahaya, M. A. Noor Aziah, S. Abdul Halim and I. Khaidzir. Interests, aspirations and Higher Education Institutions of Youth Political Support in Malaysia, Malaysian Journal of Youth Studies, 1(6), 99-116 (2009).

[13] M. Suffian. "Datuk Stephen Kalong Ningkan: Dari Pemimpin Kerajaan ke Pemimpin Pembangkang”, Panji Pendeta, Kuala Lumpur: Institut Alam dan Tamadun Melayu (ATMA) dan Ikatan Ahli Arkeologi Malaysia,739-769 (2013).

[14] NSTP Research and Information. The number of unopposed BN victories. pp. 177-179 (2017).

[15] P. Bustein. "Voter Turnout and the National Election Studies." Political Analysis (2011).

[16] P. M. Ayoub. When States Come Out: Europe's Sexual Minorities and the Politics of Visibility, New York: Cambridge University Pres (2016).

[17] R. B. Russell, J. Breed, and G. J. Barton. Conservation analysis and secondary structure prediction of the sh2 family of phosphotyrosine binding domains. FEBS Lett. 304, 15-20 (1992).

[18] R. Davies. The text of the seventeenth annual lecture of the Welsh Political Archive at the National Library of Wales, delivered at the Examination Hall of the Old College (2003).

[19] R. Kimberlee. Why don't young people vote at general elections. Journal of Youth Studies, 5 (1), 85-97 (2002).

[20] S. G. Sarjit, H. Mohd Razali, T. and Ahmad Tarmizi. Analisis pola sokongan dan pengaruh politik belia minoriti Siam menjelang PRU-13. In: Shamsul Amri Baharuddin, Mansor Mohd Noor (eds) PRU-13: Siapa pilihan pengundi? Institut Kajian Etnik (KITA), Bangi (2013).

[21] S. Ishak. Politik Suara Rakyat. Pulau Pinang: Penerbit Universiti Sains Malaysia (2014).

[22] U. Sekaran, and R. Bougie. Research Methods for Business: A Skill-Building Approach, 6th Edition (2013).

[23] UNYA. "Youth Taking Action to Implement the 2030 Agenda" in Utusan Malaysia (14 Mei, 2016). Hari Belia Negara 2016sederhana tetapi penuh pengisian. Retrieved http://www.utusan.com.my/ gaya-hidup / rekreasi /hari -belia -negara -2016 sederhana-tetapipenuh-pengisian-1.325895\#sthash.txvcWhgP.dpuf (2016)

[24] Ulbig, Stacy G., and Tamara Waggener. "Getting Registered and Getting to the Polls: The Impact of Voter Registration Strategy and Information Provision on Turnout of College Students.", Political Science \& Politics APSC, 44(3), 544-51 (2011).

[25] Utusan Online. Selesa Belia Melayu Kurang Mengundi. Retrieved http:// ww1. utusan. com. my/ utusan/ info. asp?y $=2008 \& d t=0226 \& p u b=U t u s a n \_$Malaysia\&sec $=$Bicara_Agama\&pg =ba 01.htm (accessed on 26 February 2016).

[26] Utusan Online. SPR, Melayu Perlu Berubah. Retrieved http://ww1.utusan.com.my/utusan/info.asp?y=2007\&dt=0930\&pub =utusan_malaysia\&sec=rencana \&pg=re_03.htm\&arc=hive (accessed on 30 September 2017).

[27] Y. Mohammad Agus. UMNO Leadership. Malay Political Culture. Int. Journal of Admin. And Governance, 2(1), 30-35 (2016). 